\title{
THE ARRANGEMENT OF CHILD PROTECTION INSTITUTIONS IN INDONESIA BASED ON THE 1945 INDONESIAN CONSTITUTION
}

\author{
${ }^{1}$ Encik Muhammad Fauzan, ${ }^{2}$ Ariyanti Arifta \\ 12 Faculty of Law, University of Trunojoyo Madura, Bangkalan, Indonesia \\ 1*encik.fauzan@trunojoyo.ac.id, 2ariyantiarifta@gmail.com
}

\begin{abstract}
Children have constitutional rights as stipulated in the 1945 Indonesian Constitution. The implementation of children's rights requires the formation of institutions that protect children's rights in accordance with the 1945 Indonesian Constitution and how the existence of child protection institutions that have been in Indonesia today. The research aims to provide the basis for the establishment of child protection institutions and the arrangement of child protection institutions in Indonesia. This research method uses normative research with a statute approach. The results of this study indicate that the implementation of child protection requires special institutions. The existence of two child protection institutions, namely The Indonesian Children Protection Commission (ICPC) and a National Commission for Children Protection (NCCP), require institutional arrangements so that authority does not overlap.
\end{abstract}

\section{Keywords: Protection, Constitutionality, Institution, Children Rights}

\section{Introduction}

There are three child protection institutions in Indonesia, which are the Indonesian Children Protection Commission (hereinafter referred to as ICPC), the National Commission for Children Protection (hereinafter referred to as NCCP), and the Indonesian Children Protection Agency (hereinafter referred to as ICPA). The three institutions have an important role in protecting children from all forms of violence that can harm children as the nation's next generation.

ICPC is an independent state institution established to increase the effectiveness of children protection in Indonesia. It was formed through article 74 paragraph 1 of Law Number 23 of 2002 concerning Children Protection (hereinafter referred to as Law Number 23 of 2002 concerning Children Protection) which later underwent amendments to Law Number 35 of 2014 concerning amendments to the Law Number 23 of 2002 concerning Children Protection (hereinafter referred to as Law Number 35 of 2014 amendments to Law Number 23 of 2002 concerning Children Protection). ICPC is mandated to receive public complaints. This is an effort to map 
the protection of Indonesian children. The legal basis for the ICPC is Presidential Decree Number 77 of 2003 concerning the Indonesian Children Protection Commission.

Prior to the existence of the Children Protection Law which was also the basis for the formation of the ICPC by the government, in 1997 ideas began to emerge about the importance of establishing an institution that plays a role in children protection. This is because at that time there were many cases of violence against children. Therefore, as a follow-up to this case, based on the Decree of the Minister of Social Affairs Number 81 / HUK / 1997 concerning the Formation of Children Protection Institutions (hereinafter referred to as the Minister of Social Affairs Decree No. 81 / HUK / 1997 concerning the Establishment of Child Protection Institutions), CPI was formed by a number of activists and government officials at the regional level.

Hierarchically, the presence of ICPC is higher than that of NCCP because ICCP is an institution formed by the government based on a law, while NCCP is a NonGovernmental Organization (NGO) formed based on a Decree of the Minister of Social Affairs. So as an official government agency, ICCP has the obligation or responsibility to accommodate all cases related to deprivation of children's rights as a form of protection. However, when viewed from the point of view of its initial establishment, NCCP was established earlier, which was established in 1998, than ICPC, which was established in 2002. This research attempts to make a comparison of the two commissions regarding the authority to supervise and protect children. This is because, from the media reports, the two commissions are fighting for each other's existence in providing supervision and protection for matters relating to children's rights.

In 2017, the Chairperson of the Fulfillment of Children's Rights said that as determined through the extraordinary national forum that NCCP had changed its new name to ICPA. ICPA was the first name used when this institution was first formed. The return of the name from NCCP to ICPA aims to avoid dualism and misunderstanding between NCCP and ICPC, which is official government institution. This forum also resulted in a decision to revoke the mandate given to Arist Merdeka Sirait, who was previously the chairman of NCCP.

However, NCCP is still standing and chaired by Arist Merdeka Sirait. The chairman of NCCP emphasized that the organization he leads is an official 
organization, which was formed by a number of elements including the Ministry of Social Affairs (hereinafter referred to as the Ministry of Social Affairs) in 1998. The legal basis for establishing the NCCP organization is still valid today. This then received a response from Khofifah Indar Parawansa, as the minister of social affairs at the time, that NCCP and ICPA were legitimate and recognized institutions, both registered with the Ministry of Law and Human Rights. The Ministry of Social Affairs also coordinates the two institutions.

The similarity in the name "commission" in the ICPC and NCCP has often caused controversy. This research focuses on ICPC and NCCP, both of which have the same goal of providing supervision and protection of children's rights. It is not uncommon for misconceptions to arise about basic differences that can be understood by the wider community. Based on the background of study above, several problems in this study can be formulated as follow:

1. What is the constitutionality of establishing a children protection institution?

2. How should the institutional arrangement for children protection in Indonesia be structured?

\section{Methods}

\section{Type of Research}

The research was conducted on ICPC and NCCP as objects of analysis. Therefore, the type of research used in this study is normative legal research. Normative legal research is research focused on studying the application of positive legal norms or norms (Jonaedi "Efendi and Johnny Ibrahim, 2018). The method or positive legal norms referred to is in Law Number 35 of 2014, amendments to Law Number 23 of 2002 concerning Children Protection.

\section{Research Approach}

In this study, a research approach was used to answer the formulation of problems related to the legal issues discussed. There are two approaches that are considered capable of being part of the analytical instrument in this study. The research approaches are:

1) Legislative Approach (Statute Approach), this approach is carried out by examining all laws and regulations related to the legal issue being handled (Marzuki, 2015). Because normative legal research is always closely related 
to law, this approach is the first and foremost approach that must be in this research. It reviews The Law Number 35 of 2014, amendments to Law Number 23 of 2002 concerning a Children Protection, to be precise in article 1 number 12 which explains that society and the government are one of the elements that are obliged to guarantee the protection of children. As normative legal research, the 1945 Constitution of the Republic of Indonesia is the main reference in this research.

2) Conceptual Approach (Conceptual Approach) is a study of legal concepts such as sources of law, legal institutions and so on. This approach comes from the views and doctrines that have developed in legal science (Johan Nasution, 2008). In addition to a statutory approach, a supporting approach is also needed to strengthen the analysis of legal issues, and a conceptual approach is also carried out. ICPC and NCCP are two institutions that have the same interest, namely providing protection for children. Therefore, it is necessary to have the right concept through the views and doctrines of legal experts to make arrangements for the existence of children protection institutions in Indonesia.

\section{Legal Material Sources}

Primary legal materials are the main legal materials used in normative legal research. The primary legal materials from this research are:

1) The 1945 Constitution of the Republic of Indonesia

2) Law of the Republic of Indonesia Number 23 of 2002 concerning Children Protection (State Gazette of the Republic of Indonesia of 2002 Number 109, Supplement to the State Gazette of the Republic of Indonesia Number 4235)

3) Law of the Republic of Indonesia Number 35 of 2014 concerning amendments to Law Number 23 of 2002 concerning Children Protection (State Gazette of the Republic of Indonesia of 2014 Number 297, Supplement to the State Gazette of the Republic of Indonesia Number 5606).

4) Presidential Decree Number 77 of 2003 concerning the Indonesian Child Protection Commission. 
Secondary legal materials are legal materials that assist or support primary legal materials and then strengthen the explanation in them. Secondary legal materials used in this research are books and journals.

The first technique for collecting legal materials is ensuring the existence of child protection institutions in Indonesia, whether they are government agencies or Non-Governmental Organizations (NGO), and also ensuring the legal basis of these institutions. This is done by accessing the official website of ICPC, which is an official government agency, and NCCP as a non-governmental organization (NGO). In addition, social media accounts from these institutions were also searched, such as Instagram, Twitter and Facebook. After ensuring the existence of children protection institutions, the next step is looking for the basic norms contained in the 1945 Constitution of the Republic of Indonesia as a reference for the formation of children protection institutions in Indonesia. Then the next step is looking for other regulations that are a source of support for the establishment of child ren protection institutions. Next is collecting theories related to basic norms, institutions, and the concept of rights regulation through books that can be used as references, so that later solutions will be obtained to answer legal issues from this research.

This research uses inductive legal material analysis techniques. Inductive legal material processing explains about a specific matter then draws it into general conclusions. In addition, this study also uses legal reasoning that is correlated with basic legal norms and positive legal norms as a characteristic of normative legal research.

\section{Discussion}

\section{Constitutionality of the Establishment of Children Protection Institutions}

Indonesia is a constitutional state that upholds human rights. Human rights are one of the substances that must be contained in the 1945 Constitution of the Republic of Indonesia as a manifestation of providing legal protection to the Indonesian people who are actually the holders of the highest sovereignty in the people's democratic system which is also implemented in Indonesia. Human rights are known as rights inherent in human nature (Idrus Affandi and Karim Suryadi, 2009). 
The debate about the regulation of human rights in the laws and regulations in Indonesia was already underway when the state was founded. This debate has started since the drafting of the 1945 Constitution, then the climax point in this debate is whether the state should regulate human rights or not. So it is necessary to understand also the history of human rights regulation in the 1945 Constitution of the Republic of Indonesia and the inclusion of children's rights as a part of human rights which requires protection.

Human rights arrangements began to be regulated in Indonesian legislation since Indonesia enacted the Constitution of the Republic of the United States of Indonesia in 1949. However, there were no regulations regarding children's rights at that time. Then when Indonesia enacted the 1945 Constitution of the Republic of Indonesia as a constitution, the content of articles on children's rights was not included in it. Indonesia underwent several constitutional changes until finally it became the 1945 Constitution of the Republic of Indonesia. This law has been amended four times. The contents of the articles in the 1945 Constitution of the Republic of Indonesia as basic norms, which include content on human rights, experience dynamic changes in accordance with the development of the constitution. the constitution is the overall basic rule which binds the administrators of state power (organs state) in administering the state and its relationship with the people both as citizens and individuals. In this case, the state and the people are obliged to comply with the rules has been listed in the constitution as a basic rule. Basic rules this is the fundamental law in the formation of regulations other laws (Fauzan, 2016).

The results of the first amendment still do not include children's rights in the constitution. Human rights regulations are also still general in nature, limited to the right to organize and express opinions either orally or in writing, which in this case is contained in article 28 of the 1945 Constitution of the Republic of Indonesia, the first amendment.

The proposal for the inclusion of children's rights in the 1945 Constitution of the Republic of Indonesia originated from the second session of amendments proposed by Taufiqurrohman Ruki. He stated that what is part of human rights as a citizen is the State's recognition of human rights. Rights that cannot be reduced under any circumstances and by anyone, women's rights and children's rights, as well as 
other restrictions stipulated by law which are then proposed in the contents of the new article.

Through long debates, finally the formulation of the regulation of human rights was decided in a plenary session held on August 18, 2000 by the Annual Session - the 9th Indonesian People's Consultative Assembly as a result of the second amendment to the 1945 Republic of Indonesia Constitution. a separate chapter related to human rights, whereas after this second amendment, human rights began to have its own chapter in the constitution with articles that were refined from before. One of them is the content of the article on children's rights.

The rights of children in the 1945 Constitution of the Republic of Indonesia as a result of the second amendment are regulated in Article 28B paragraph (2) which states that every child has the right of survival, growth and development, and the right of protection and discrimination. In line with the dynamics of the development of the constitution, the 1945 Constitution of the Republic of Indonesia was amended four times. For the third and fourth amendments, there were no changes to the contents of the article on children's rights. Therefore, the content of articles on children's rights in the current constitution remains in Article 28B paragraph (2) of the 1945 NRI Constitution.

The rules regarding the protection of children's rights have been affirmed in the constitution, and strengthened in Law Number 39 of 1999 concerning Human Rights in article 52 paragraph 2 which discusses children's rights. However, it will only be in vain if the rules that have been designed in such a way through a series of debates are not realized with a real protection.

One of the steps that can be taken to provide protection for children can be realized by giving responsibility to certain agencies that specifically handle child protection. Then it becomes urgent to form a child protection agency. Children are the nation's biggest investment in the future, so protecting children is also a shared responsibility of the whole nation.

The first children protection institution in Indonesia was ICPA which was initiated in 1997 with a protection work system in each region. Then ICPA felt the need to establish an independent statute, so NCCP was formed as a national ICPA statute in 1998. The initiative to form NCCP was a form of public concern for violence against children that occurred before 1998. The main reason for the establishment of 
NCCP was as a form concern for the importance of solidarity in efforts to protect children. After the existence of NCCP as a forum for public complaints against all forms of child abuse, many facts were revealed about the increasing number of violence against children.

Seeing the increasing number of violence against children, the government is obliged to find a solution to this problem. With the increasing number of cases of violence against children scattered in several provinces in Indonesia, in 2002 Law Number 23 of 2002 concerning Child Protection was formed which later changed to Law Number 35 of 2014 amendments to Law Number 23 of 2002 concerning Child Protection. The government is one of the elements that is obliged to provide protection for children. This is emphasized in article 1 number 12 of Law Number 35 of 2014 concerning amendments to Law no. 23 of 2002 concerning Child Protection. Therefore, as a form of government responsibility for child protection, a protection institution was formed as the government's responsibility for the rights that need to be protected. This institution is ICPC, which was formed in 2002 and became an official government agency.

After the existence of ICPC and NCCP, the public can file complaints to these institutions in case of violence against children. However, the existence of ICPC and NCCP has not been able to minimize the rate of violence against children. This is based on the fact that in 2006 the number of acts of violence against children reached 3.02 percent, which means that in every ten thousand Indonesian children around three hundred and two of them have the opportunity to experience violence. Violence against children occurs in various provinces throughout Indonesia with various intensities.

The following is data on public complaints to the ICPC and NCCP regarding cases of violence against children as a whole. In every amount of violence against children, sexual violence always dominates violence against children. If a percentage, sexual violence always ranks above $50 \%$ each year, while the rest can be in the form of emotional violence, neglect, and physical violence.

Figure 2 


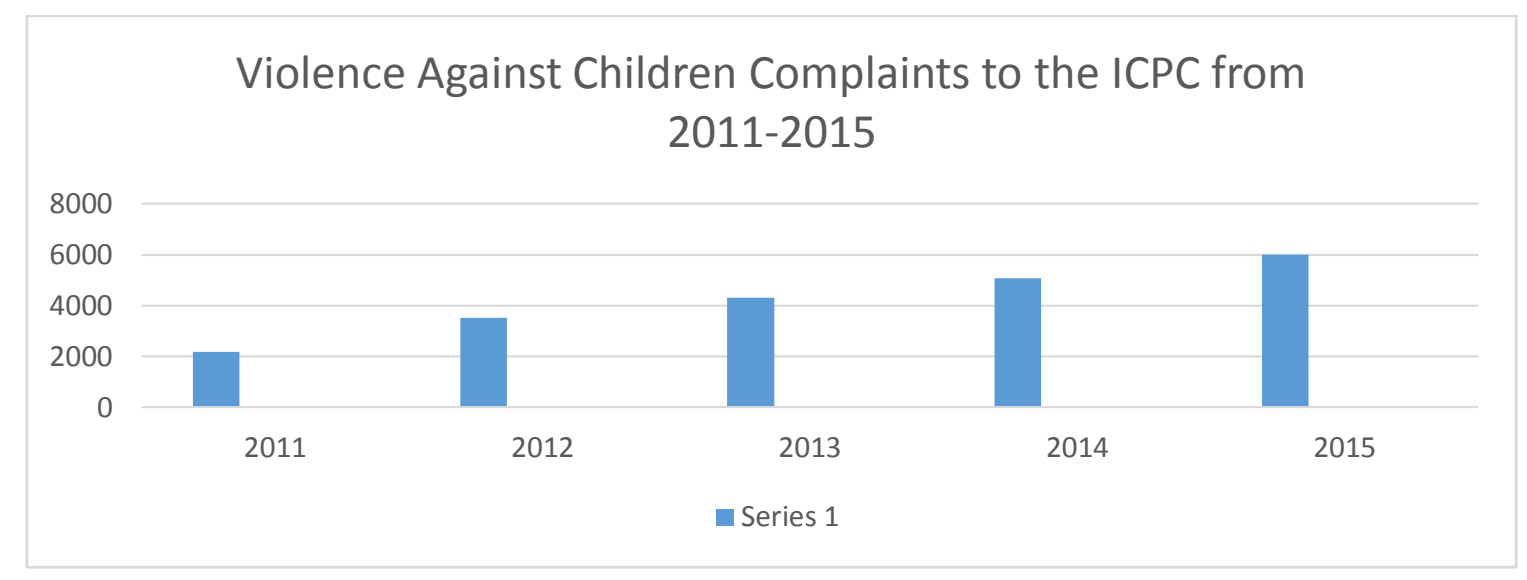

Sumber : https://www.kpai.go.id

Based on the graph above, it can be understood that the number of complaints to ICPC has increased drastically every year. The existence of ICPC as a forum for public complaints against acts of violence against children has not been able to be a solution to reduce and minimize the number of violence against children. It is very necessary to do an evaluation to maximize the existence of this state institution so that what is the main objective of establishing ICPC by the government can be achieved.

Apart from making complaints to ICPC, which has the status of a state institution, the public can also make complaints to NCCP, which is a nongovernmental organization. The following is a graph of the number of complaints of violence against children to NCCP from 2011 to 2015.

Figure 3 


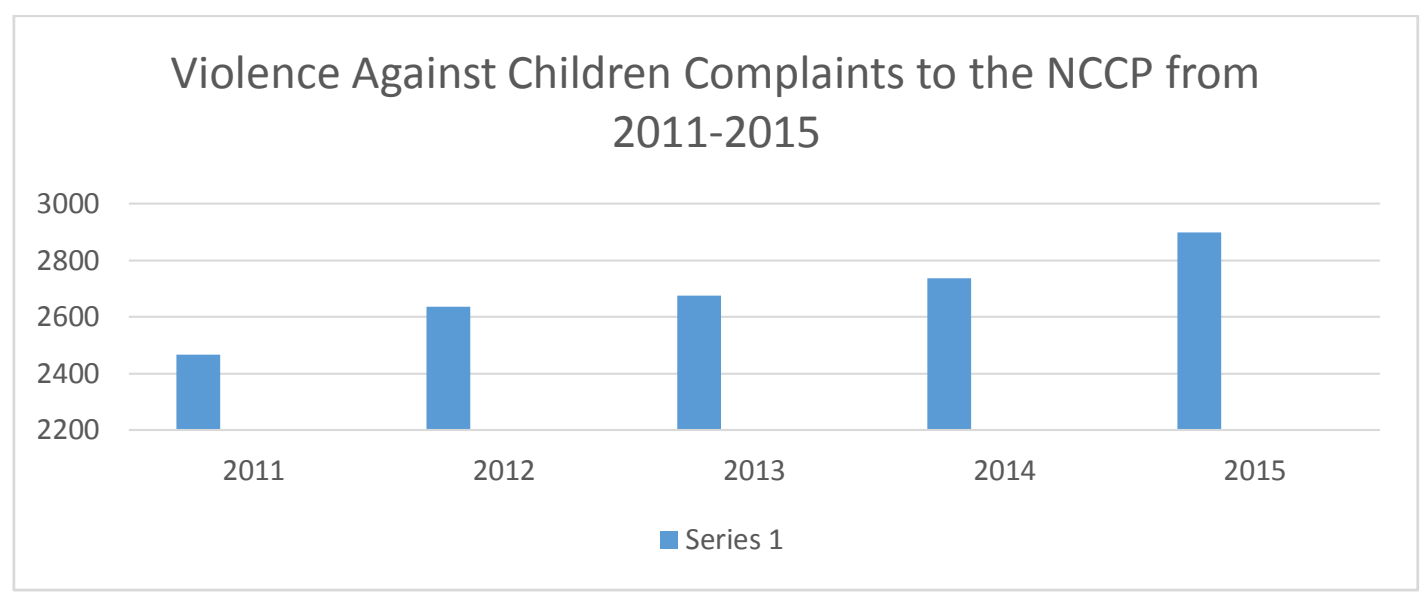

Source: https://m.liputan6.com

Based on the graph above, complaints of violence against children to the NCCP have also increased every year, but the increase is not greater than that of complaints against the ICPC. Therefore, it can be concluded that the public mostly complained to the ICPC. In a vulnerable five (5) year period, from 2011 to 2015, the ICPC has received complaints of violence against children ranging from 2,000 to 6,000 people. Meanwhile, NCPC only received complaints ranging from 2,400 to 2,800 people.

The constitution of the state of Indonesia is the 1945 Constitution of the Republic of Indonesia which was agreed to be the basis for the state by state administrators. The constitution is the overall basic rule which binds the administrators of state power (organs state) in administering the state and its relationship with the people both as citizens and individuals. In this case, the state and the people are obliged to comply with the rules has been listed in the constitution as a basic rule. Basic rules this is the fundamental law in the formation of regulations other laws (Fauzan, 2013).

State Law Number 35 of 2014 concerning amendments to State Law Number 23 of 2002 concerning Child Protection is constitutionally valid. It is a government policy in the form of rules that are obeyed by the community. This is in line with the mandate of the 1945 Constitution of the Republic of Indonesia in Article 28B paragraph (2) that one of the rights of children is to get protection. Meanwhile, the existence of the NCCP also refers to Article 28 of the 1945 Constitution of the Republic of Indonesia and Article 28C paragraph (2), that everyone has freedom of association and has the right to advance themselves collectively to develop society, nation and 
state. NCCP is an institution consisting of associations of several unified parties and have the same goal of advancing themselves collectively by providing protection for children's rights for the continuation of a better life as a nation and state. Although not a state institution, the NCCP has a legal basis and is recognized for its existence in Indonesia. This situation is also in line with what is stated in the 1945 Constitution of the Republic of Indonesia so that the constitutionality of ICCP and NCCP is clear and legally valid.

\section{The Importance of Institutional Arrangements for Child Protection}

The laws and regulations as the legal basis for the existence of state institutions outside the 1945 Constitution of the Republic of Indonesia in Indonesian constitutional practice consist of various types, causing uncertainty and inconsistency. This is due to the absence of regulations regarding the types of laws and regulations and the proper forms of state institutions (Harimurti, 2019). According to the Big Indonesian Dictionary $(K B B I)$ a commission is a group of people appointed (given authority) by the government, the meetings and so on to carry out certain functions (tasks). Therefore, the term commission is very appropriate to be used by official government institutions. The ICPC is an independent state institution, an institution formed outside the 1945 Constitution of the Republic of Indonesia, which is appointed by the President as a rule. The legal basis for the ICPC is Presidential Decree No. 77/2003 on the Indonesian Child Protection Commission. ICPC is a form of protection from the government against children from all forms of violence and discrimination, it is an implementation of Article 28B paragraph (2) of the 1945 Constitution of the Republic of Indonesia concerning children's rights, one of which is to obtain protection guarantees.

However, prior to the ICPC, there was a child protection agency formed by a group of people together with the government. The first institution to exist as a form of child protection guarantee in Indonesia, namely the NCCP. Since 1998 the NCCP has been active in child protection in Indonesia, which is a refinement of the Children Protection Institution which was first initiated in 1997. The historical fact of the existence of the Children Protection Institution at that time was only at the regional level. As time went on, it began to spread to other areas, which at its peak was the formation of the National Children Protection Institution statuts which later changed 
the name of the Children Protection Institution to NCCP based on the Minister of Social Affairs Decree No. 81 / HUK / 1997 regarding Children Protection Institution. However, the NCCP has the status of a non-governmental organization and has been registered with the Ministry of Law and Human Rights.

Due to the similarity in the name "commission" between the ICPC and the $\mathrm{NCCP}$, it is necessary to have an arrangement so as not to cause conflict between the two institutions. As an official government agency, the existence of the ICPC is clearly important as one of the implementations of government duties in terms of child protection which is of course supported by a clear legal basis for establishing an institution. Meanwhile, the NCCP, which is a non-governmental organization, is also recognized for its existence in Indonesia as long as it does not conflict with the Law.

According to KBBI, a non-governmental organization is an organization that aims to fight for the interests of the community. NCCP is a non-governmental organization that promotes the interests of children in which children are part of society. Therefore the NCCP is a non-governmental organization. There is no specific regulation regarding NGOs, but the establishment of NGOs is adjusted to the type of legal or non-legal entity used to support the organization's activities.

Referring to the definition of NGO according to KBBI, there are 3 (three) regulations that can be used as a reference as the legal basis for NGOs:

1. State Law Number 17 of 2013 concerning Community Organizations (Law Number 17 of 2013 concerning Community Organizations) in article 1 number 1 states "social organizations are organizations that are formed and established by the community voluntarily based on the same aspirations, desires, needs, interests, activities, and goals to participate in development".

2. Law Number 28 of 2004 concerning amendments to Law Number 16 of 2001 concerning foundations (Law Number 28 of 2004 concerning amendments to Law Number 16 of 2001 concerning Foundations) in article 1 number 1 states that "a foundation is a legal entity consisting of wealth that is separated and earmarked for achieving certain goals in social, religious and humanity matters.

3. Staatsblad 1870 Number 64 concerning associations with legal entities, which was then issued Regulation of the Minister of Law and Human Rights Number 6 of 2014 concerning Ratification of Association Legal Entities, which in article 1 point 1 explains that "an association is a legal entity consisting of a group of people 
established to realizing the same purpose and certain goals in social, religious and humanity issues, and not sharing benefits for its members ".

When connected with Law Number 17 of 2013 concerning Community Organizations (ormas), it needs to be reviewed. Ormas are mass-based organizations, while NGOs are oriented towards community empowerment activities, so it is not right if NCCP as a legality NGO uses Law Number 17 of 2013 concerning Community Organizations.

Next is the State Law Number 28 of 2004 concerning amendments to the State Law Number 16 of 2001 concerning Foundations. In the organizational system of a foundation there are only supervisors, administrators and supervisors, while the NCCP is an organization based on membership, so the Law on Foundations is also inappropriate if it is made the legality of the existence of NGOs (e.g. NCCP) While Staatsblad 1870 Number 64 concerning associations with legal entities has existed since colonial times and applies in Indonesia which was later refined by the issuance of the Minister of Law and Human Rights Regulation Number 6 of 2014 concerning the Ratification of Association Legal Entities, NCCP has been established since 1998 which in at that time, there was no law on community organizations and a law on foundations. So, the legal basis for NGOs (NCCP) used is Staatsblad 1870 Number 64 concerning associations with legal entities which are certainly not mass-based organizations but organizations that are oriented towards community empowerment activities with a membership system.

The procedure for ratifying the association's legal entity is preceded by submitting an application for submission of the association's name to the Minister of Law and Human Rights. Then the name of the association that has been approved by the minister is valid for a maximum period of 60 (sixty) days. Subsequently, applications for association legal entity approval shall be made by filling in the establishment format, completing supporting documents and uploading the association's establishment deed to obtain a ministerial decision regarding the association's legal entity approval.

Because the NCCP was formed by activists and the government of the Ministry of Social Affairs at that time, the legal basis used was Decree of the Minister of Social Affairs No. 81 / HUK / 1997 so that the NCCP is under the auspices of the Ministry of 
Social Affairs. As a legally valid NGO, the NCCP has also been registered with the Ministry of Law and Human Rights and has met the requirements as determined.

The more child protection agencies there are, the better the child protection system in Indonesia will be. Because basically the emergence of child protection institutions is to uphold the rights of children protected by the state. However, in reality, the emergence of the same name "commission" in the ICPC and NCCP has actually created new conflicts between other institutions which have resulted in the struggle for the existence of the two. This has resulted in a change in the focus of the objectives of these two institutions, whose initial intention was only to provide protection for children's rights as stipulated in the Law but has now increased 1 (one) more, namely the struggle for existence.

State institutions and non-governmental organizations are 2 (two) different things. State institutions are state administrators officially formed by the government either based on the 1945 NRI Constitution or based on other regulations outside the 1945 NRI Constitution as per the hierarchy of statutory regulations. All forms of operational costs for state institutions are borne by the state. On the other hand, NGOs are supporting agencies of state institutions. NGOs are formed by a group of people and their existence is recognized as long as they are registered with the Ministry of Law and Human Rights. Operational costs also do not depend on the government, but from the internal institutions themselves, although currently with various policies NGOs can also access funds from the government.

People often think that the ICPC and NCCP are the same, because they both work within the national territory. Moreover, in recent years there has been a new conflict, the return of the name from NCCP to ICPA, because it often creates conflicts with ICPCs that have similar names. In addition, it was indicated that there was an internal conflict within the NCCP, which resulted in division and groups that wanted to return and change their name to ICPA. However, until now the NCCP and ICPA are still there and both are registered with the Ministry of Law and Human Rights. Therefore, it is necessary to organize child protection institutions in Indonesia so that there is no overlapping of authority because there are no clear rules regarding the main duties and limitations of authority between the ICPC, NCCP and ICPA. 
Because the NCCP and ICPA are NGOs, the government does not have the authority to impose restrictions on the movement of NGOs. However, it is well known that the existence of NGOs is an auxiliary institution of an official government agency, so it is not right that between government agencies and NGOs then fight for existence, thereby diverting their main task of providing protection for children.

As a state administrator, the government is obliged to provide an understanding of the existence of NGOs in Indonesia, as well as find solutions so that NGOs and official government agencies work together in eradicating violence against children, mutually develop strategies and build good relationships with the community to jointly provide protection against the child.

Basically, state institutions and NGOs cannot be compared, they are two institutions with different legal status. ICPC as a State Institution has the obligation and responsibility to the state to provide protection for children's rights. Meanwhile, the NCCP has the right to take part in protecting children's rights. However, when analyzed from the name of the institution, the use of the name National Commission seems to imply that the NCCP is a State Institution. Then in terms of legal basis, the Minister of Social Affairs Decree Number 81 / HUK / 1997 concerning Child Protection Institutions, in this decision the name listed was the Indonesian Children Protection Agency (ICPA) which was at the central level which later changed its name to NCCP. Over time there was an internal conflict within the NCCP which resulted in some people from the NCCP choosing to separate again to form a child protection institution in accordance with the initial name of the institution, namely ICPA. So, indirectly, the Minister of Social Affairs Decree Number 81 / HUK / 1997 concerning the Establishment of a Child Protection Agency becomes the legal basis for the two non-governmental organizations which are ICPA and NCCP.

The Decree of the Minister of Social Affairs Number 81 / HUK / 1997 concerning the Establishment of the Child Protection Institution, also explained that the central child protection agency is an independent, non-government institution that is a government partner. So that as a partner the government should not interfere in the internal affairs of the NCPC institution. However, in 2007 the Minister of Social Affairs Decree Number 09 / HUK / 2007 was still formed regarding the Inauguration of the National Commissioner Board for Child Protection for the 2006-2009 Period. Because the government should not interfere in this matter. So that the Decree of the 
Minister of Social Affairs Number 09 / HUK / 2007 is a form of government inconsistency.

Whereas the ICPC as a state institution should have clearly been formed by the government on the basis of Presidential Decree No. 77/2003, while the NCCP and ICPA as NGOs were formed based on the Minister of Social Affairs Decree. As the Ministry of Social Affairs is also part of the government, the government is also forming the NCCP and ICPA. In fact, the status of the NCCP and ICPA are NGOs and registered with the Ministry of Law and Human Rights. The government should not be allowed to form two institutions which have the same function. It would be ambiguous, when the NCCP was formed based on the Minister of Social Affairs Decree, but its status as an NGO and registered with the Ministry of Law and Human Rights seems as if there is a dualism of the ministry that manages the institution.

Therefore, it is necessary to make arrangements for these institutions. It would be better if there is a strengthening of the main duties and functions of the ICPC as a state institution, while the NCCP and ICPA are merged into one (1) by not using the name "Commission" so as not to cause further misunderstandings. Between state institutions and NGOs are required to work together and establish good communication so that the handling of child protection can be achieved optimally.

The use of the name commission is more appropriate for state institutions, this is based on the definition of a commission according to the KBBI that "a commission is a group of people who are authorized by the government, meetings, etc. to carry out certain functions". The NCCP was formed based on the results of the meeting, so the use of the term commission is actually also entitled to be owned by NGOs, but in this study the term commission between state institutions (ICPC) and NGOs (NCCP) becomes a problem because it triggers misunderstandings in society and causes struggles for the existence of the two institutions. the. Since the word "government" is mentioned before the word "meeting" in the meaning of commission according to the $\mathrm{KBBI}$, the government has more right to use that term.

There is also a need for mediation between the NCCP and the ICPA to reestablish a common goal and harmony in the thinking of each institution. This aims to eliminate internal conflicts that have occurred, and to build together a child protection institution with a new name according to mutual agreement, of course by not using the term commission. After that, it is important to conduct socialization to 
the community regarding the existence of the ICPC as an official government agency and child protection agency with a new name according to the agreement (ICPA and NCCP merging) and being an NGO so that there is no misunderstanding of terms and the community is not confused anymore if they want to make a complaint, against cases related to child protection.

\section{Conclusion}

a. The existence of the ICPC as a state institution is in accordance with the mandate of Article 28B paragraph (2) which states that one of the rights of children is to get protection. Meanwhile, the existence of the NCCP also refers to Article 28 of the 1945 Constitution of the Republic of Indonesia and Article 28C paragraph (2), which states that everyone has freedom of association and has the right to advance themselves collectively to develop their society, nation and state. NCCP is an institution consisting of associations of several unified parties and have the same goal of advancing themselves collectively by providing protection for children's rights for the continuation of a better life as a nation and state. So that the existence of the ICPC and the NCCP is a concrete form of the constitutionality of establishing child protection institutions.

b. It is important to organize child protection institutions between ICPC as a state institution, NCCP as an NGO and ICPA as an NGO to provide an understanding of the differences between each child protection agency in Indonesia by taking into account the legal basis of each institution and the impact of its existence on society.

\section{REFERENCES}

Affandi, Idrus dan Suryadi, Karim. (2009). Hak Asasi Manusia (HAM). Universitas Terbuka.

Badan Pusat Statistik dan Kementerian Negara Pemberdayaan Perempuan. (2007). Fenomena Tindak Kekerasan Terhadap Perempuan dan Anak. Jakarta. Badan Pusat Statistik dan Kementerian Negara Pemberdayaan Perempuan. 
Efendi, Jonaedi dan Ibrahim, Johnny. (2018). Metode Penelitian Hukum Normatif dan Empiris. Prenadamedia Group.

Fauzan, Encik Muhammad. (2013). Fungsi Sosiologis Undang-undang Dasar Negara Republik Indonesia Tahun 1945 Dalam Memenuhi Hak-hak Masyarakat, Jurnal Masalah-Masalah Hukum, 42 (3).

Fauzan, Encik Muhammad. (2017). Hukum Tata Negara Indonesia. Setara Press.

Nasution, Johan. (2015). Metode Penelitian Ilmu Hukum. Mandar Maju.

Marzuki, Peter Mahmud. (2015). Penelitian Hukum Edisi Revisi. Adhitya Andrebina Agung.

Harimurti, Yudi Widagdo. (2019). Kelembagaan Negara dalam Praktek Ketatanegaraan Indonesia. Inteligensia Media,

\section{Websites:}

https://www.kpai.go.id diakses pada hari senin, 15 juni 2020, pada pukul 09.04 wib. https://m.liputan6.com diakses pada hari senin, 15 juni 2020, pada pukul 09.15 wib. https://m.hukumonline.com diakses pada hari sabtu, 14 maret 2020, pada pukul 19.12 wib. 